\title{
CSF2 wt Allele
}

National Cancer Institute

\section{Source}

National Cancer Institute. CSF2 wt Allele. NCI Thesaurus. Code C49778.

Human CSF2 wild-type allele is located in the vicinity of 5q31.1 and is approximately $19 \mathrm{~kb}$ in length. This allele, which encodes granulocyte-macrophage colony-stimulating factor protein, is involved in the production, differentiation, and function of both macrophages and granulocytes. 